\title{
Implementation of Good School Governance through "PADI ASI" Movement towards Effective Schooling
}

\author{
Siti Ismuzaroh ${ }^{1}$, Fathur Rokhman ${ }^{2}$, Etty Soesilowati ${ }^{3}$, Agus Wahyudin ${ }^{4}$ \\ ${ }^{1,2,3,4}$ Management Education, Graduate School, Universitas Negeri Semarang, Indonesia \\ ${ }^{1}$ Corresponding email: iisthoha95@gmail.com
}

\begin{abstract}
Previous study on school performance results remaining less satisfactory both academic achievement and non-academic. Therefore, the investigators assumed that it happened because of poor governance. Researchers believe that school performance is influenced by internal organizational factors reinforced by good school governance principles. The aim of this best practice is to describe the implementation of good school governance through the PADI ASI movement towards an effective school. Good school governance is essentially about a system, process, and set of rules governing relationships between various stakeholders. The GSG is intended to govern this relationship and prevent significant mistakes in corporate strategy and to ensure that errors can be corrected immediately. The technique and data analysis used in this research is a comparative descriptive method, which compares the data before and after the implementation of the problem solving strategy. Based on the theory study and the result of the impact of applying the principles of good school governance through the PADI ASI movement in SMAN 1 Batang, it can be concluded that there is a positive impact on school performance outcomes, both student and teacher achievement, both academic and non-academic.
\end{abstract}

Keywords: good school governance, PADI ASI, effective school.

\section{Introduction}

At present, the management of financing standards and process standards has become the center of the attention of school citizens, both teachers, parents and outside communities. The crisis of school trust in school managers can lead to a decline in the quality of education in general. Positive culture in schools will be disrupted, and consequently organizational goals will not be achieved. Based on the above conditions, then one of the strategies in finding solutions that are currently actual, namely empowering corporations by implementing the principles of good school governance (GSG) through the "PADI ASI" movement (Obey Rules, Discussion, Accountability, Socialization, and Implementation) to reach effective schools. This is in line with the results of the study by Renny, et. Al., (2013) which concluded that the Implementation of Good Corporate Governance can affect directly on corporate performance by EVA, and also shows affect indirectly through firm size. Meanwhile, Ahmad Dahro (2013) states that the basic principles of GUG are fully applied by leaders to students, but the lack of involvement of lecturers and students in the process of formulating formal institutions, indicates the implementation of GUG principles, especially on the principles of transparency, enforcement of rules, Community participation and response to various formal rules have not been fully implemented. Preferably the formal rules of the institution (academic status and guidelines, SOP) must be carried out in each unit transparently, enforced explicitly and involving all components. Meanwhile, Ahmad Dahro (2013) states that the basic principles of GUG are fully applied by leaders to students, but the lack of involvement of lecturers and students in the process of formulating formal institutions, indicates the implementation of GUG principles, especially on the principles of transparency, enforcement of rules, Community participation and response to various formal rules have not been fully implemented. The research results of Wahyudin (2009) stated that good governance has a partial influence on organizational performance.

Based on the description above, this study wants to find out the extent of the influence of good school governance through the PADI ASI movement towards effective schools. The purpose of this study was to describe the application and impact of the results of the application of good school governance through the PADI ASI movement.

The benefits of this research are to improve the managerial competence of principals in realizing an effective school and provide input to supervisors as reference 
material for coaching activities towards the management of education units towards effective schools.

\section{Methods}

The place of Implementation was in SMAN 1 Batang,Central Java. The implementation time was 5 (five) years; 2013 to 2017. Subject of Implementation was teachers, administrative staff, students at SMAN 1 Batang, Central Java. Techniques and data analysis used in this paper was descriptive comparative that compares data before and after application of problem solving strategy done. To know the result of applying the principles of good school governance, some instruments are needed. The instruments used were questionnaires of teachers, TU staff, committees and students. There is also a result of implementation of this strategy obtained through document studies.

Based on the principles of good corporate governance, the operational stages of the implementation of good school governance in schools are as follows:

a. Schools partner with school committees with a principled independence, a state where schools are managed professionally without conflict of interest and influence from any party that is not in accordance with applicable laws and regulations (Obedient Rules).

b. Transparency, i.e openness in implementing decision-making process and openness in expressing material information (through discussion with school people).

c. Accountability, namely clarity of functions, implementation and accountability of school organizations so that school management is implemented effectively (Socialization of the results of discussion to school residents).

d. Accountability, i.e suitability in school management of applicable legislation (Program socialization and Accountability Report)

e. Fairness, that is fairness and equality in fulfilling the rights of stakeholders arising under the applicable agreement and law (Implementation).

\section{Results and Discussion}

\section{A. Description of Early Conditions}

Based on the documentation study, the achievement of SMA N 1 Batang in the academic year 2012/2013 still not in accordance with expectations, it is seen in the academic data in which the achievement of UN at the district level is ranked 2 (two) for IPS study program, even in the academic year 2011/ 2012 (RSBI), the results of the SMA N 1 Batang District level are ranked 5th for IPA, and 7th for IPS with rank 107th (IPA) and 106 (IPS) at the provincial level. This is very apprehensive given the input of students of SMA N 1 Batang with an average of pure UN over other high schools in Batang Regency. The OSN (Olimpiade Sains Nasional) achievement is only 5 people who pass $O S P$ (Olimpiade Sain Provinsi), and no one has managed to qualify for national level. Including sports achievement in POPDA activity at Regency level, SMA N 1 Batang has never become the first winner.

Based on documentation study of teacher's scientific work in continuous profession program, it is found that the teacher who succeeded in preparing the class action report is only five people from 60 people (10\%), despite previous training of PTK.

Based on the analysis of preliminary condition data through questionnaires and document studies obtained several causes effectiveness in achieving the vision, mission and goals of school effectively, among others.

a) Lack of openness in deciding a particular program.

b) Stakeholder engagement is still not Optimal

c) Involvement of educators and education personnel in implementing the program has not been evenly distributed.

d) Awarding of students and achieving teachers has not been implemented optimally.

\section{B. Description of The End of Condition}

Based on document studies of the application of good school governance principles to the achievement of vision, mission and school goals for five years has increased significantly. This can be seen from the graph as follows: 
1. Academic Achievement of Students and Teachers.

Table 1. Comparison of Academic and NonAcademic Achievement of Students and Teachers Before and After the Application of GSG.

\begin{tabular}{|c|c|c|c|}
\hline $\begin{array}{c}\text { Descriptio } \\
\text { n } \\
\end{array}$ & Pre GSG & Before GSG & After GSG \\
\hline $\begin{array}{l}\text { UN } \\
\text { achieveme } \\
\text { nt at } \\
\text { provincial } \\
\text { level }\end{array}$ & $\begin{array}{l}\text { NATU-RAL } \\
\text { SCIENCES: } \\
179 \\
\text { SOCIAL } \\
\text { STUDIES: } \\
106\end{array}$ & $\begin{array}{l}\text { NATU-RAL } \\
\text { SCIENCES: } 45 \\
\text { SOCIAL } \\
\text { STUDIES: } 36\end{array}$ & $\begin{array}{l}\text { NATU-RAL } \\
\text { SCIENCES: } 6 \\
\text { SOCIAL } \\
\text { STUDIES: } 12\end{array}$ \\
\hline $\begin{array}{l}\text { OSN } \\
\text { Achievem } \\
\text { ents }\end{array}$ & $\begin{array}{l}5 \text { students } \\
(19 \%)\end{array}$ & $\begin{array}{l}\text { OSP: } \\
\text { students } \\
\text { OSN: } 1 \\
(39 \%)\end{array}$ & $\begin{array}{l}\text { OSP: } 11 \text { students } \\
(42 \%) \\
\text { OSN: } 1 \\
\text { Silver medal }\end{array}$ \\
\hline
\end{tabular}

OSN Participants in Provincial Level

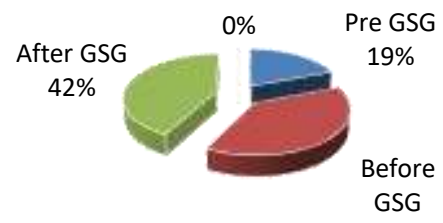

Figure 1. Comparison Graph of Students' Achievement in Inter-Cycle Provincial Level OSN

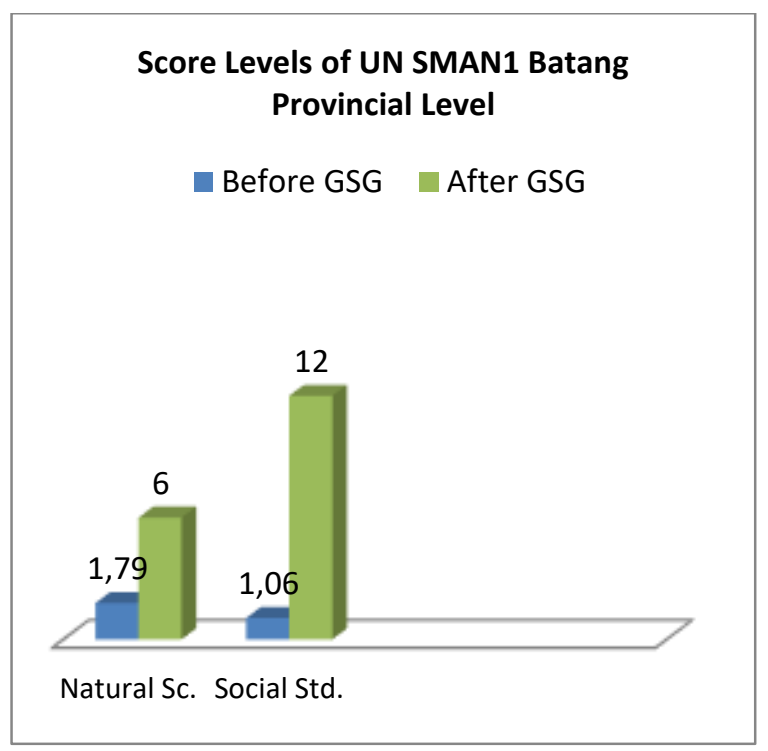

Figure 2. Achievement Graph of UN Rank of Inter-Cycle Provincial Level

\section{Conclusion}

Based on the study of the theory and the impact of the implementation of the principles of good school governance through the PADI ASI movement in SMAN 1 Batang, it can be concluded that there is a positive impact on school performance outcomes, both student and teacher achievement, both academic and academic. This shows that through the implementation of good governance will provide trust and a conducive climate for the citizens of the school in carrying out its obligations in developing quality teaching and learning process. Through this also, public confidence increases. The implementation of good school governance can be continued and developed with communication innovation by the principal in order to obtain more optimal results. Supervisors and heads of education and cultural offices need to support the implementation of good school governance through the "PADI ASI" movement. The establishment of good school governance is expected to be followed and developed by the school.

\section{References}

Komariah A, et al. (2004). Visonary Leadership towards Effective Schooling. Bandung: Earth Literacy.

Lukviarman, N. (2016). Corporate Governance towards Conceptual Strengthening and Implementation in Indonesia. Solo: PT. Era Adicitra Intermedia.

Mulyasa. (2004). Being a Principal Professional. In the Context of Successful SBM and CBC. Bandung: Teens Rosdakarya.

Novalinda, Y. (2007). Public Perception on the Implementation of Good Governance and Relationship with Performance (Case Study: City Government Administration South. Undergraduate Program, Faculty of Economics Gunadarma University.

Renny, dkk. (2013). "Implementation of Good Corporate Governance and Its Impact on Corporate Performance: The Mediation Role of Firm Size (Empirical Study from Indonesia)". Global Business and Management Research: An International Journal, 5(2\&3): 91-104.

Sedarmiyati. (2012). Good Governance. Good Governance. Part Three Revised Edition. Bandung: CV. Andar Maju

Shipley, R. (2007). Good Governance Principles for the Cultural Heritage Sector: Lessons from Intenational Experience. The international journal of 
bussiness in society, vol.8 Iss 2 pp. 214228.

Sumarto, H. (2009). Innovation, Participation, and Good Governance. Jakarta: Yayasan Obor Indonesia.

Trakulmututa, J. (2013). Factors Affecting the Achievement of Good governance in HRM: The Empirical Study of Local Governments in Southern Part of
Thailand. International Journal of Business and Social Science Vol. 4 No. 7; July 2013.

Wahyudin, A. (2009). “Analisis Hubungan Motivasi, Good Governance Terhadap Kinerja Institusi Pendidikan yang Dimoderasi Karakteristik Biografi”. Jurnal Dinamika Akutansi, Unnes. Vol 1(1): 14-22. 